\title{
Pandangan Citra Brand Kopi Janji Jiwa di Kalangan Mahasiswa
}

\author{
Rayni Delya Hafni1, Assyifa Amelia Azzahra2, Khairunnisa Rosdiani3 \\ 1raynidelya@gmail.com \\ 1.2.3Ilmu Komunikasi, Fakultas Ilmu Sosial, Universitas Negeri Jakarta
}

\begin{abstract}
ABSTRAK
Peningkatan konsumsi kopi terus terjadi di masyarakat Indonesia, bahkan Indonesia disebut sebagai negara dengan masyarakat yang tingkat konsumsi kopinya terbesar di dunia. Kopi tidak hanya di nikmati oleh beberapa golongan, namun kopi dapat dinikmati oleh seluruh kalangan lintas generasi dan gender. Janji Jiwa merupakan salah satu kedai kopi atau brand yang ada di Indonesia. Kedai ini telah dibuka sejak tahun 2018 dan cukup menyita perhatian publik. Saat ini Janji Jiwa terus mengembangkan brand dan produk kopinya untuk dapat semakin baik dan dapat bersaing dengan para pesaingnya Salah satu konsep yang diunggulkan pada brand Janji Jiwa adalah konsep fresh-to-cup yaitu menggunakan kopi dari petani lokal Indonesia. Tujuan dari penelitian ini adalah untuk mengetahui pandangan masyarakat mengenai citra brand kopi Janji Jiwa dan strategi yang dapat digunakan untuk meningkatkan citra brand di kalangan mahasiswa saat ini. Penelitian ini menggunakan metode kualitatif dengan teknik pengumpulan data berupa wawancara mendalam. Populasi pada penelitian ini adalah Mahasiswa. Dari hasil penelitian, menunjukan bahwa : (1) Kualitas layanan yang diberikan dinilai baik oleh mahasiswa, (2) Nama brand yang unik menjadi ketertarikan sendiri untuk beberapa orang, (3) Strategi pemasaran yang kuat dan mempengaruhi psikologis, (4) Pembelian disebabkan oleh faktor sosial dan psikologis, (5) Perbedaan pendapat mengenai cita rasa kopi. Dari hasil penelitian tersebut, Janji Jiwa dapat terus menggunakan strategi pemasarannya namun brand ini juga harus terus berinovasi dalam produk kopi agar produk juga dapat disukai oleh semua kalangan dan meningkatkan image positif brand.
\end{abstract}

Kata Kunci : Citra brand, Periklanan, Strategi pemasaran

\begin{abstract}
Increased coffee consumption continues to occur in Indonesian society, even Indonesia is referred to as the country with the highest level of consumption in the world. Coffee is not only enjoyed by several groups, but coffee can be enjoyed by all circles across generations and genders. Janji Jiwa is one of the coffee shops or brands in Indonesia. This shop has been opened since 2018 and is enough to attract public attention. Currently Janji Jiwa continues to develop its brands and coffee products to be better and be able to compete with supporters One of the
\end{abstract}


concepts that are featured in the Janji Jiwa brand is the fresh-to-cup concept of using coffee from local Indonesian farmers. The purpose of this study is to study the public's view of the Kopi Janji Soul brand image and strategies that can be used to improve brand image among students today. This study uses qualitative methods with data collection techniques using in-depth interviews. The population in this study were students. From the research results, it shows that: (1) The quality of services provided by students, (2) Unique brand names are a special attraction for some people, (3) Strong marketing strategies and psychological influence, (4) social and psychological factors, (5) Differences of opinion regarding the taste of coffee. From the results of this research, Janji Jiwa can continue to use its marketing strategy but this brand must also continue to innovate in coffee products so that the product can also be promoted by all groups and enhance a positive brand image.

Keywords: Advertising, Brand image, Marketing strategy

\section{PENDAHULUAN}

Sepanjang tahun 2015 sampai tahun 2019, permintaan minuman kopi terus meningkat. Minat masyarakat pada kopi selama akhir dekade ini terus bertambah tinggi. Kopi tidak hanya menjadi minuman yang identik untuk diminum oleh kalangan tua saja, namun kopi juga dinikmati oleh anak-anak muda saat ini. Selain itu tidak hanya lintas generasi, kopi juga dinikmati dari berbagai gender, yang biasanya dinikmati oleh kaum pria, kini banyak kaum perempuan yang turut menggemari minum kopi.

Menurut data dari Kementrian Pertanian dalam laman pertanian.go.id (2019), produksi kopi nasional dari tahun 2015 hingga tahun 2018 terus mengalami peningkatan. Pada tahun 2015, jumlah produktivitas kopi se-Indonesia sebesar $707 \mathrm{~kg} / \mathrm{ha}$. Sedangkan pada tahun 2018, jumlah produktivitas kopi meningkat menjadi sebesar $782 \mathrm{~kg} / \mathrm{ha}$.

Indonesia, menjadi salah satu negara dengan tingkat konsumsi kopi terbesar di dunia. Menurut data dari International Coffee Organization (ICO) dalam laman databoks.katadata.co.id (2018), tingkat konsumsi kopi masyarakat Indonesia mencapai 4,6 juta lb atau sebasar 2 juta kilogram sepanjang tahun 2016/2017. Berdasarkan angka tersebut, Indonesia menempati urutan ke enam setalah Russia dalam daftar 10 negara dengan konsumsi kopi terbesar di dunia tahun 2016/2017. 


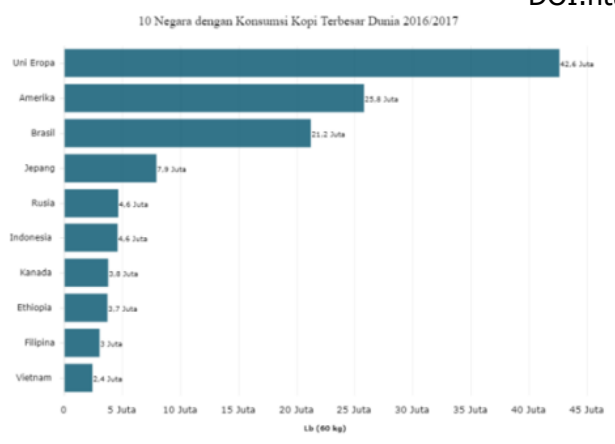

Sumber : Databoks.katadata.co.id. (2018). "Indonesia Masuk Daftar Negara Konsumsi Kopi Terbesar Dunia”. https://databoks.katadata.co.id/datapublish/2018/12/12/indonesia-masuk-daftar-negara-konsumsi-kopi-terbesar-dunia

Jika dilihat dari data kementrian pertanian dalam laman databoks.katadata.co.id (2018), diprediksi bahwa tingkat konsumsi kopi nasional akan terus bertambah hingga mencapai 370 ton pada tahun 2021. Berdasarkan data dari kementrain pertanian, konsumsi kopi pada tahun 2016, mencapai 250 ton, dan mengalami pertumbuhan sebesar 10,54\% menjadi 276 ton pada tahun 2017.

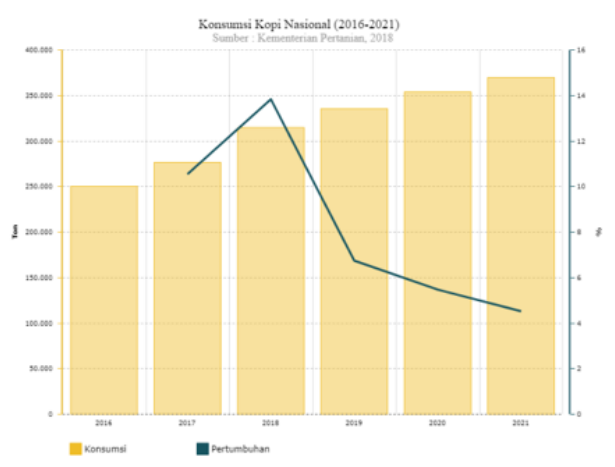

Gambar 2. Konsumsi Kopi Nasional (2016-2021)

Sumber : Databoks.katadata.co.id. (2018). “2021, Konsumsi Kopi Indonesia Diprediksi Mencapai 370 Ribu Ton”. https://databoks.katadata.co.id/datapublish/2018/07/31/2021-konsumsi-kopi-indonesia-diprediksi-mencapai-370-ribu-ton

Berdasarkan data di atas, tingkat pertumbuhan konsumsi kopi masyarakat di Indonesia paling tinggi berada sepanjang tahun 2017 hingga tahun 2018. Tingkat pertumbuhan konsumsi kopi masyarakat menjacapi $13,83 \%$ atau sebesar 314 ton.

Adanya peningkatan konsumsi kopi pada masyarakat Indonesia selama tahun 2016 hingga 2018, secara tidak langsung diakibatkan tingginya minat masyarakat Indonesia dalam meminum kopi. Hal tersebut disebabkan karena pertumbuhan kedai-kedai kopi di Indonesia. 
Akhir-akhir ini, banyak muncul kedai-kedai kopi baru di Indonesia. Hal ini terjadi karena gaya hidup generasi milenial saat ini yang gemar meminum kopi bersama teman-teman. Menurut Syarifudin ketua dari Speciality Coffee Association of Indonesia (SCAI) dalam ekonomi.bisnis.com, perilaku minum kopi dikarenakan peminum kopi di Indonesia lebih senang meminum kopi di kedai kopinya dengan melakukan kegiatan lain dibandingkan mereka meminum kopi instan. Hal itu menjadikan potensi bisnis dalam kuliner meningkat.

Dalam laman ekonomi.bisnis.com pertumbuhan kedai kopi hingga akhir tahun 2019, diprediksi mengalami peningkatan sebesar $15 \%$ - 20\%, hal tersebut mengalami kenaikan dari tahun 2018 yang hanya mencapi 8\% hingga 10\%. Dari data-data tersebut, mengindikasikan bahwa banyak kemunculan-kemunculan kedai kopi baru di Indonesia. Salah satu kedai kopi yang ada adalah kedai kopi “janji jiwa”.

Kedai kopi "Janji Jiwa" merupakan salah satu kedai kopi yang ada di Indonesia. Kedai kopi ini pertama kali buka pada tahun 2018 di ITC Kuningan, Jakarta Selatan. Menurut pemilik kedai kopi "Janji Jiwa", Billy Kurniawan dalam Kusumawardhani (2019), sepanjang pertengahan tahun 2019, sudah ada 300 outlet kedai kopi "Janji Jiwa" di 50 kota besar yang ada di Indonesia.

Kedai kopi "Janji Jiwa" memiliki tag line yaitu "Kopi dari Hati”. Janji jiwa mengambil konsep fresh-to-cup dengan penyajian kopi yang diambil dari petani lokal Indonesia (Lunarabrand.com, 2018). Menurut humas dari kedai kopi "Janji Jiwa", Christanty dalam Kusumawardhani (2019), kopi yang biasa digunakan dalam pembuatan kopi pada kopi "Janji Jiwa" dalah kopi berjenis robusta yang berasal dari Sumatra.

Selain kedai kopi "Janji Jiwa", terdapat beberapa kedai kopi yang menjadi pesaing dari kedai kopi ini. Menurut Womentalk.com, terdapat 5 kedai kopi susu yang terkenal di Jakarta. Kelimat kedai kopi tersebut yaitu kedai kopi "Kopi Soe", kedai kopi "Janji Jiwa", kedai kopi "Fore Coffee", kedai kopi "Kopi Kenangan", dan kedai kopi "Kulo". Berdasarkan hal tersebut, peneliti melihat bahwa perlu adanya branding yang kuat dalam membedakan kedai kopi "Janji Jiwa" dengan kedai kopi lain yang ada di Jakarta maupun di Indonesia. Selain itu, perlu adanya strategi periklanan yang baik, dalam memaksimalkan potensi pasar yang ada bagi kedai kopi "Janji Jiwa".

Berdasarkan data-data di atas, peneliti bertujuan untuk mengetahui pandangan masyarakat terkait brand dari kopi "Janji Jiwa" tersebut. Selain itu, peneliti juga ingin mengetahui strategi yang tepat, untuk digunakan dalam promosi kopi "Janji Jiwa" terlebih pada 
generasi milenial seperti mahasiswa saat ini. Adapun manfaat yang diberikan pada penelitian ini yaitu, peneliti ingin mengembangkan strategi pemasaran yang tepat untuk digunakan dalam periklanan kedai kopi "Janji Jiwa" dan memberikan gambaran citra brand terkait kopi "Janji Jiwa" yang ada pada kalangan mahasiswa. Oleh karena itu kami ingin meninjau Bagaimana pandangan citra brand kopi janji jiwa dikalangan mahasiswa UNJ? Bagaimana mahasiswa UNJ memilih kopi janji jiwa sebagai kopi andalan? Dampak mahaiswa UNJ meminum kopi janji jiwa?

\section{METODE PENELITIAN}

Untuk melakukan penelitian mengenai pandangan citra brand kopi Janji Jiwa di kalangan mahasiswa, peneliti memutuskan untuk menggunakan metode penelitian kualitatif. Penelitian kualitatif adalah penelitian yang lebih menekankan pemahaman terhadap masalah yang terjadi dalam kehidupan sosial yang didasari oleh kondisi yang realitas, kompleks dan terperinci. Penelitian ini tidak menggunakan statistika untuk mendapat hasilnya, melainkan melalui proses analisis data yang kemudian peneliti interpretasikan. (Anggito \& Setiawan, p. 9)

Penelitian ini menggunakan mahasiswa yang ada di Jakarta yang gemar minum kopi sebagai populasinya, karena mahasiswa sekarang sangat identik dengan pergi minum kopi baik untuk sekedar berkumpul dengan temannya atau alternatif ketika ingin mencari suasana baru untuk mengerjakan tugas, salah satunya kedai kopi Janji Jiwa yang cukup ramai pembelinya dari kalangan mahasiswa. Metode penelitian kualitatif akan membantu peneliti dalam mendeskripsikan bagaimana pandangan citra brand kopi Janji Jiwa di kalangan mahasiswa.

Dalam penelitian kualitatif, pengumpul data atau instrumen adalah peneliti sendiri. Sehingga peneliti adalah key instrument dalam penelitian ini dan melakukan turun lapangan untuk mendapatkan informasi yang dibutuhkan. Dalam penelitian ini, pengumpulan data dilakukan dengan melakukan wawancara kepada pihak sampel.

Sampel dari penelitian ini diambil dari 3 mahasiswa Universitas Negeri Jakarta yang gemar minum kopi dan gemar mengkonsumsi kopi Janji Jiwa. Pengumpulan data dilakukan dengan melakukan wawancara kepada pihak sampel hingga informasi yang didapat memadai.

Selanjutnya data yang telah didapat dirangkum dan dipilih hal-hal pokok yang berkaitan dengan tujuan dari penelitian ini, serta memfokuskan pada hal-hal yang penting serta menentukan polanya. Setelah direduksi, data disajikan dan disusun untuk selanjutnya diambil kesimpulan atas data-data tadi. Kesimpulan berisi mengenai hasil penelitian yang menjawab apa yang menjadi fokus penelitian berdasarkan hasil analisis data. Kesimpulan yang semulanya kabur akan semakin jelas dan diperkuat dengan data-data yang telah diperoleh dan dianalisis. 
Penelitian ini meneliti satu variabel yaitu variabel citra brand kopi Janji Jiwa di kalangan mahasiswa. Citra dari brand nantinya akan memengaruhi bagaimana perilaku dan keputusan konsumen selanjutnya.

\section{PEMBAHASAN}

\section{Pandangan Mengenai Citra Brand Kopi Janji Jiwa}

Dalam mengetahui citra Kopi Janji Jiwa sebagai salah satu Brand kopi di Indonesia yang cukup banyak diminati oleh kawula muda ini, kami fokus terhadap tiga hal yang berkaitan dengan pembangunan citra dari Brand itu sendiri, yaitu faktor yang menyebabkan rasa ketertarikan untuk mencoba Brand ini, kesan yang diberikan oleh Brand kepada konsumen atau pembeli, dan pandangan atau pendapat konsumen itu sendiri mengenai Brand Kopi Janji Jiwa.

Berdasarkan hasil penelitian yang dilakukan melalui wawancara dan observasi dengan ketiga informan, faktor yang memengaruhi ketertarikan mereka untuk mencoba Kopi Janji Jiwa adalah pilihan rasa kopi yang beragam, ciri khas dari rasa kopi yang dijual di Kopi Janji Jiwa, serta ajakan dari orang terdekat. Setelah mencoba produk Kopi Janji Jiwa, ada informan yang merasa puas dikarenakan rasanya yang enak dan pelayanan dari Kopi Janji Jiwa yang ramah, juga ada informan yang merasa tidak puas dikarenakan rasa dari produk Kopi Janji Jiwa yang kurang memuaskan dibandingkan Brand kopi lain.

Perbedaan juga terjadi dalam pandangan para informan mengenai Kopi Janji Jiwa, perbedaan ini didasari pada perbedaan penilaian dari masing-masing informan. Perbedaan penilaian ini terfokus pada dua hal yakni strategi pemasaran dari Kopi Janji Jiwa dan kualitas pelayanan yang ditawarkan oleh Kopi Janji Jiwa. Salah satu informan menganggap strategi pemasaran Kopi Janji Jiwa menarik, yaitu melakukan penulisan kata-kata penyemangat pada gelas kopi. Kemudian, informan lain merasa Kopi Janji Jiwa memiliki nama Brand yang unik, sehingga menarik minat untuk membeli. Toko Kopi Janji Jiwa juga dinilai memiliki desain yang menarik. Produk Kopi Janji Jiwa juga dinilai memiliki rasa yang relatif enak. Dari segi pelayanan, salah satu informan menyatakan kualitas pelayanan yang diberikan oleh Kopi Janji Jiwa dinilai baik.

Hasil penelitian ini sesuai dengan ulasan teori mengenai citra (merek) yang mendukung, kuat, dan unik menjadi faktor yang membangun citra sebuah merek atau Brand. Kemudian, citra 
sebuah merek atau Brand juga merupakan hasil dari strategi pemasaran dari Brand itu sendiri. Melalui hasil penelitian melalui wawancara di atas, dapat dikatakan bahwa Kopi Janji Jiwa memiliki citra yang positif dikarenakan Brand Kopi Janji Jiwa mendukung, kuat, dan unik. Kopi

Janji Jiwa dikatakan mendukung karena Kopi Janji Jiwa merupakan salah satu Brand kopi, yang mana berdasarkan data statistik, Indonesia mengalami peningkatan dalam mengonsumsi kopi. Kemudian, Kopi Janji Jiwa memiliki kekuatan dalam hal strategi pemasaran, sebagaimana yang dijelaskan sebelumnya, yaitu melakukan penulisan kata-kata penyemangat pada gelas kopi. Selanjutnya, Kopi Janji Jiwa merupakan Brand kopi yang unik, hal ini tercermin dengan jelas melalui penamasan Kopi Janji Jiwa itu sendiri yang menjadi daya tarik konsumen untuk membeli produk dari Kopi Janji Jiwa.

\section{Pemilihan Kopi Janji Jiwa Sebagai Kopi Andalan}

Pada pembahasan kedua, kami melihat mengenai bagaimana Mahasiswa UNJ memilih Kopi Janji Jiwa sebagai kopi andalan mereka. Berdasarkan temuan wawancara yang dilakukan pada ketiga narasumber yang merupakan Mahasiswa Ilmu Komunikasi Universitas Negeri Jakarta, beberapa dari mereka menjelaskan bahwa ketertarikan mengonsumsi Kopi Janji Jiwa bukan dikarenakan adanya senja dan puisi, namun mereka menjelaskan bahwa mengonsumsi kopi menjadi suatu kesukaan. Kemudian, Kopi Janji Jiwa sendiripun memiliki makna yang berbeda-beda kepada setiap konsumen yang mengonsumsi kopinya. Keberadaan Kopi Janji Jiwa memiliki ciri khas tersendiri yang mampu menyentuh psikologi seseorang yang dapat menimbulkan pemaknaan tersendiri bagi masing-masing konsumen, baik dalam segi penamaan produknya, rasanya, dan nama tokonya. Beberapa narasumber kami mengakui bahwa penamaan dari produk itu sendiri memiliki makna bagi diri individunya, namun ada pula narasumber kami yang menjelaskan bahwa dirinya meminum Kopi Janji Jiwa tanpa ada pemaknaan apapun.

Berdasarkan hasil wawancara tersebut, dapat terlihat bahwa beberapa mahasiswa membeli Kopi Janji Jiwa karena adanya pengaruh sosial yang diberikan oleh orang-orang disekitarnya, yaitu teman disekitarnya, namun ada juga yang terpengaruh secara psikologis, dimana pembelian dilakukan karena adanya motivasi untuk membeli dari diri sendiri. Motivasi tersebut dibentuk karena adanya kebutuhan mengenai kopi yang ada pada diri mahasiswa sekarang ini. Pada dasarnya, pengaruh-pengaruh tersebutlah yang menimbulkan perilaku pembelian Kopi Janji Jiwa dari mahasiswa Ilmu Komunikasi Universitas Negeri Jakarta.

\section{Dampak Mahasiswa Meminum Kopi Janji Jiwa}

Kemudian, wawancara kami lanjutkan untuk melihat seberapa berdampaknya mahasiswa meminum Kopi Janji Jiwa. Ketika kami mengajukan pertanyaan kepada narasumber kami yang 
merupakan Mahasiswa Ilmu Komunikasi Universitas Negeri Jakarta, mereka menjelaskan bahwa meminum kopi memiliki dampak tersendiri bagi masing-masing personal, namun tidak ada dampak yang signifikan yang terlihat. Mereka menjelaskan bahwa meminum kopi membuat perasaan mereka menjadi lebih baik, hingga merasa memiliki energi baru jika meminum kopi. Disamping itu, seorang narasumber juga menjelaskan bahwa meminum kopi merupakan kegiatan

yang menjadi kebiasaan dilakukannya, apabila tidak meminum kopi dirinya merasa ada sesuatu yang kurang. Selanjutnya, berbicara mengenai dampak yang dihasilkan setelah meminum Kopi Janji Jiwa dibandingkan kopi-kopi lainnya, seorang narasumber menjelaskan bahwa tidak ada dampak yang ditimbulkan baik secara psikologis atau apapun. Namun, berbeda dengan yang lainnya, kedua narasumber menjelaskan bahwa Kopi Janji Jiwa memiliki cita rasa yang khas, dimana tidak ada kopi lainnya yang memiliki rasa kopi seperti Kopi Janji Jiwa. Bahkan, Kopi Janji Jiwa memiliki cita rasa khas kopi yang ciamik, dimana ada perpaduan yang pas antara manis dan pahit pada kopi tersebut. Hal ini berhubungan dimana adanya evaluasi yang dihasilkan dari keputusan pembelian sebuah produk yang dilakukan oleh individu. Evaluasi pasca pembelian dapat dirasakan oleh individu, dan apabila evaluasi tersebut berdampak positif, maka keputusan pembelian terhadap produk yang sama dapat dilakukan secara berulang-ulang. Seperti halnya ketiga narasumber yang telah kami wawancarai. Keputusan pembelian mereka terhadap Kopi Janji Jiwa memiliki evaluasi pasca pembelian yang baik, sehingga menimbulkan dampak positif mengenai kopi tersebut.

\section{SIMPULAN}

1. Kualitas pelayanan. Brand Janji Jiwa dinilai dapat memberikan kualitas pelayanan yang baik. Baiknya kualitas tersebut dilihat dari sikap pelayannya yang ramah. Yang mana hal ini menjadi sebuah kelebihan dari brand Janji Jiwa karena dapat meninggalkan kesan positif terhadap konsumen sehingga konsumen dapat melakukan pembelian - pembelian selanjutnya.

2. Nama brand menarik. Nama brand yang unik yaitu Janji Jiwa dinilai menarik oleh beberapa informan hal ini membuat brand tersebut dapat membekas di ingatan masyarakat.

3. Strategi pemasaran dinilai kuat. Janji jiwa menggunakan strategi pemasaran yang cukup kuat, unik dan menarik karena brand ini menggunakan tulisan di setiap produk "Janji Jiwa" dimana tulisan tersebut dapat berupa kalimat penyemangat yang dapat menyentuh dan mempengaruhi psikologis atau emosional dari konsumen seperti merasa senang, haru, bahagia dan lainnya. 
4. Faktor sosial dan psikologis mempengaruhi pembelian. Pembelian yang dilakukan dapat disebebkan oleh faktor sosial yaitu ajakan atau dorongan dari orang lain seperti teman, sahabat ataupun keluarga. Faktor lain yang menyebabkan pembelian dari brand janji jiwa adalah faktor psikologis yang diartikan bahwa pembelian disebabkan oleh adanya kesan atau pengalaman yang mungkin pernah di alami oleh konsumen pada brand janji jiwa.

5. Cita rasa. Dalam cita rasa, setiap orang memiliki perbedaan untuk menilai tingkat kenikmatan dari produk Janji Jiwa. Ada beberapa orang yang mungkin merasa bahwa takarannya pas atau cukup dan ada beberapa yang menilai bahwa kopi terlalu manis atau

lainnya. Hal ini dapat membuat perbedaan pendapat dan pandangan terhadap citra brand dalam hal rasa.

\section{DAFTAR PUSTAKA}

\section{Buku :}

Keller, Kevin Lane. 2003. Strategi Brand Manajement, Building Maesurement and Managing Brand Loyality.Upper Sadle Fiver, NJ, Pearson Education Internasional

Moriarty, Sandra (2017). Advertising. Jakarta: Kencana

\section{Jurnal :}

Nugrahaningrum, Ari Widyastuti W., Mulyati, Rina. (2018). Citra Merekstarbucksdanloyalitas Konsumen Mahasiswa Di Yogyakarta

Pradata, Irwansyah. (2015). Pengaruh Citra Merek, Kepribadian Merek Dan Pengetahuan Produk Terhadap Niat Pembelian Kopi Kapal Api Dan Top Kopidi Surabaya Analisis Citra Merek Dan Kualitas Layanan Starbucks Coffee Terhadap Loyalitas Pelanggan Di Kota Bogorrandini, Elen Mutia. (2018).

Suzandoko, Theo H, Dkk. (2019). Pengaruh Daya Tarik Iklan Dan Citra Merek Terhadap Keputusan Pembelian Produk Luwak White Coffee Di Kota Surabaya (Impact Of Advertising Appeal And Brand Image On Purchase Decision Luwak White Coffee Product In Surabaya)

\section{Internet :}

Kementrian Pertanian Republik Indonesia. (2019). "Produktivitas Kopi Menurut Provinsi di Indonesia,2015-2019". https://www.pertanian.go.id/home/?show=page\&act=view\&id=61

Databoks.katadata.co.id. (2018). "Indonesia Masuk Daftar Negara Konsumsi Kopi Terbesar Dunia”. $\quad$ https://databoks.katadata.co.id/datapublish/2018/12/12/indonesia-masukdaftar-negara-konsumsi-kopi-terbesar-dunia 
Databoks.katadata.co.id. (2018). “2021, Konsumsi Kopi Indonesia Diprediksi Mencapai 370 Ribu Ton”. https://databoks.katadata.co.id/datapublish/2018/07/31/2021-konsumsikopi-indonesia-diprediksi-mencapai-370-ribu-ton

Zuhriyah, Dewi Amintuz. (2019). "Industri Kedai Kopi Ditaksir Tumbuh 20\% Tahun Ini”. https://ekonomi.bisnis.com/read/20190822/12/1139918/industri-kedai-kopi-ditaksirtumbuh-20-tahun-ini

Kusumawardhani, Noer Qomariah. (2019). "Kopi Janji Jiwa, Bertahan dengan Racikan Robusta Sumatra". $\quad$ https://www.republika.co.id/berita/gayahidup/kuliner/19/06/26/ptois4414-kopi-janji-jiwa-bertahan-dengan-racikanrobusta-sumatra

Womantalk.com. (2019). "5 Kopi Susu Kekinian Yang Paling Hits Di Jakarta". https://today.line.me/id/pc/article/5+Kopi+Susu+Kekinian+Yang+Paling+Hits +Di+Jakarta-z9Vke5 